\title{
Alarming hypoxemia during one-lung ventilation in a patient with respiratory bronchiolitis-associated interstitial lung disease
}

\author{
[Hypoxémie inquiétante pendant la ventilation unilatérale chez une patiente \\ souffrant de pneumopathie interstitielle respiratoire associée à une bronchiolite]
}

Anis S. Baraka MD FRCA, Samar K. Taha MD, Chadi I. Yaacoub MD

Purpose: To report a patient with respiratory bronchiolitis-associated interstitial lung disease (RB-ILD) who developed severe hypoxemia during one-lung ventilation (OLV).

Clinical features: A 27-yr-old female, ex-smoker presented with productive cough and dyspnea of 18-month duration. The chest $x$ ray revealed diffuse abnormalities involving both lungs consisting of interstitial emphysema with irregular shadowing. Preoperative $\mathrm{PaO}_{2}$ was $88 \mathrm{mmHg}$ and pulmonary function tests showed moderate obstructive disease. The patient underwent right open lung biopsy. After induction of anesthesia, a left double lumen tube was inserted and its position verified with auscultation and fibreoptic bronchoscopy. Upon initiation of OLV, the patient developed severe hypoxemia and the $\mathrm{PaO}_{2}$ dropped from $500 \mathrm{mmHg}$ during twolung ventilation (TLV) to $50 \mathrm{mmHg}$. Hypoxemia was readily corrected by resuming TLV.

Conclusion: The severe hypoxemia during OLV in this patient with RB-ILD may be attributed to impaired hypoxic pulmonary vasoconstriction. Other causes were not excluded. Caution is warranted when initiating OLV in these patients.

Objectif : Présenter une patiente atteinte de pneumopathie interstitielle respiratoire associée à une bronchiolite (PIR-B), compliquée d'une hypoxémie sévère pendant la ventilation unilatérale (VUL).

Éléments cliniques : Une femme de 27 ans, ancienne fumeuse, a consulté pour une toux productive et une dyspnée qui duraient depuis 18 mois. La radiographie pulmonaire a révélé des anomalies diffuses aux deux poumons, formées par l'emphysème interstitiel caractérisé par des opacités irrégulières. $\mathrm{La} \mathrm{PaO}_{2}$ préopératoire était de 88 $\mathrm{mmHg}$ et les épreuves fonctionnelles respiratoires ont montré une affection obstructive modérée. La patiente a subi une biopsie ouverte du poumon droit. Après l'induction de l'anesthésie, une sonde à dou- ble lumière gauche a été insérée et sa position vérifiée par auscultation et fibroscopie bronchique. Dès le début de la VUL, une sévère hypoxémie est apparue et la $\mathrm{PaO}_{2}$ a chuté de $500 \mathrm{mmHg}$ à 50 $\mathrm{mmHg}$ pendant la ventilation bilatérale (VBL). L'hypoxémie a été rapidement corrigée par la reprise de la VBL.

Conclusion : L'hypoxémie sévère qui s'est produite pendant la VUL chez une patiente atteinte de PIR-B peut être attribuée, entre autres causes, à l'altération vasoconstrictive pulmonaire hypoxique. La prudence est de mise quand on procède à la VUL dans de telles circonstances.

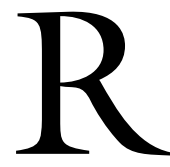
ESPIRATORY bronchiolitis-associated interstitial lung disease (RB-ILD) is a very rare disease described almost exclusively in cigarette smokers. ${ }^{1,2}$ The disease is often confused with other diffuse parenchymal lung diseases, especially idiopathic pulmonary fibrosis. ${ }^{3,4}$ Chest radiograph shows diffuse fine reticulonodular interstitial infiltrates, bronchial wall thickening and prominence of the peribronchovascular interstitium. ${ }^{5}$ The pathologic findings show a mononuclear inflammation of the submucosa of the respiratory bronchioles ${ }^{4,6}$ dominated by the presence of tan-brown pigmented macrophages $3,4,6,7$ and fibrous scarring extending to the surrounding alveolar walls. ${ }^{5}$

An extensive search through Medline, Embase, Cochrane and other databases failed to reveal any report on the use of one-lung ventilation (OLV) in patients with RB-ILD. This report presents a young

From the Department of Anesthesiology, American University of Beirut-Medical Center, Beirut, Lebanon.

Address correspondence to: Dr. Anis Baraka, American University of Beirut, Department of Anesthesiology, P.O. Box 11 0236, Beirut, Lebanon. Phone: 961-1-350000; Fax: 961-1-744464; E-mail: abaraka@aub.edu.lb

Anesthesiology departmental funding.

Accepted for publication October 28, 2002.

Revision accepted January 8, 2003. 
female with RB-ILD who underwent open lung biopsy and developed severe hypoxemia during OLV.

\section{Case report}

The patient was a 27 -yr-old female, $(159 \mathrm{~cm}, 51 \mathrm{~kg})$, who was admitted to the hospital for recurrent productive cough, moderate dyspnea, sputum expectorations and occasional hemoptysis of 18 month duration. The patient was a heavy cigarette smoker who stopped smoking two months before. She was not receiving any medications preoperatively. Physical examination revealed a temperature of $37.6^{\circ} \mathrm{C}$, a blood pressure of $125 / 90 \mathrm{mmHg}$, a heart rate of 100 beats. $\mathrm{min}^{-1}$ and normal heart sounds. Chest auscultation revealed diffuse bilateral ronchi. Complete blood count and electrolytes were normal; urine analysis revealed numerous red blood cells. Alpha-1-antitrypsin was $1.84 \mathrm{~g} \cdot \mathrm{L}^{-1}$ (normal), sweat chloride was 15 $\mathrm{mmol} \cdot \mathrm{L}^{-1}$ (normal) and a PPD test for tuberculosis was negative. No endobronchial lesions were visualized at bronchoscopy and culture of bronchial lavage fluid was positive for hemophilus influenza type B $20.000 \cdot \mathrm{mL}^{-1}$.

The chest $x$-ray revealed diffuse interstitial infiltrates with honey combing. Diffuse abnormalities involving both lungs and all lobes were present on the computed tomography scan of the chest. These were more extensive in the upper and mid zones and consisted of interstitial emphysema with irregular interstitial shadowing. No lymph node enlargement in the hila or mediastinum nor any evidence of bronchiectasis were seen.

Arterial blood gases on room air showed a $\mathrm{PaO}_{2}$ of $88 \mathrm{mmHg}$, a $\mathrm{SpO}_{2}$ of $97 \%$, a $\mathrm{PaCO}_{2}$ of $38 \mathrm{mmHg}$ and a $\mathrm{pH}$ of 7.45 . Moderate obstructive disease with a $15-20 \%$ decrease in obstruction with bronchodilators was documented by pulmonary function tests (PFT) with a carbon monoxide diffusion capacity predicted of $22.45 \mathrm{~mL} \cdot \mathrm{min}^{-1} \cdot \mathrm{mmHg}^{-1}$ and pre-bronchodilators of $18 \mathrm{~mL} \cdot \mathrm{min}^{-1} \cdot \mathrm{mmHg}^{-1}$.

The preoperative differential diagnosis included alpha-1-antitrypsin deficiency, histiocytosis and sarcoidosis. The patient was scheduled for right thoracotomy for an open lung biopsy and possible lobectomy. She was premedicated with diazepam $5 \mathrm{mg}$ po and glycopyrrolate $0.2 \mathrm{mg} \mathrm{im}$. An 18-gauge peripheral angiocatheter was inserted for $i v$ access, and a total of 700 $\mathrm{mL}$ of lactated Ringer's solution was given. The patient was monitored intraoperatively with electrocardiography, an arterial line, end-tidal capnography and pulse oximetry. After preoxygenation with 100\% $\mathrm{O}_{2}$, anesthesia was induced with lidocaine $75 \mathrm{mg}$, propofol $100 \mathrm{mg}$, cisatracurium $8 \mathrm{mg}$, sufentanil 20 $\mu \mathrm{g}$ and midazolam $2 \mathrm{mg}$. A left 35-French doublelumen tube (DLT) was used; correct placement of the tube was verified by chest auscultation and by fibreoptic bronchoscopy (FOB). Position of the DLT was rechecked after positioning of the patient in the left lateral decubitus at an angle of around $45^{\circ}$ to the plane of the operating table. Anesthesia was maintained with isoflurane $0.4-1.8 \%$ in $100 \% \mathrm{O}_{2}$ and the lungs were ventilated with a tidal volume of 10 $\mathrm{mL} \cdot \mathrm{kg}^{-1}$ at a respiratory rate of 12 breaths $\cdot \mathrm{min}^{-1}$ and an $\mathrm{I} / \mathrm{E}$ ratio of $1: 2$. Intraoperatively the blood pressure ranged between $105 / 65-140 / 80 \mathrm{mmHg}$, and the heart rate ranged between 90 and 110 beats. $\mathrm{min}^{-1}$.

During two-lung ventilation (TLV), results of arterial blood gas analysis were: $\mathrm{PaO}_{2} 500 \mathrm{mmHg} ; \mathrm{SO}_{2}$ $100 \% ; \mathrm{PaCO}_{2} 36 \mathrm{mmHg}$; and $\mathrm{pH} 7.42$. One minute following initiation of OLV the $\mathrm{SpO}_{2}$ started to drop, and the patient developed severe hypoxemia with an $\mathrm{SpO}_{2}$ dropping down to $85 \%$ at the end of the procedure which lasted ten minutes and was limited to lung biopsy; the results of arterial blood gas analysis at that time were: $\mathrm{PaO}_{2} 50 \mathrm{mmHg} ; \mathrm{SO}_{2} 85 \%$; $\mathrm{PaCO}_{2} 44$ $\mathrm{mmHg}$; and $\mathrm{pH} 7.38$. Proper positioning of the DLT and adequate ventilation of the dependent lung were confirmed. Following lung biopsies from the right upper lobe and the right lower lobe, TLV was resumed, and the $\mathrm{SpO}_{2}$ increased to $100 \%$. Arterial blood gas analysis were: $\mathrm{PaO}_{2} 420 \mathrm{mmHg}$; $\mathrm{SO}_{2} 100 \%$; $\mathrm{PaCO}_{2} 39 \mathrm{mmHg}$; and $\mathrm{pH} 7.40$.

At the end of surgery, neuromuscular blockade was reversed with neostigmine $2.5 \mathrm{mg}$ and glycopyrrolate $0.5 \mathrm{mg}$, and the patient was extubated. Histopathology showed patchy interstitial lung disease consistent with RB-ILD.

\section{Discussion}

This report presents a case of severe hypoxemia during OLV in a young female with RB-ILD who underwent surgery for open lung biopsy. OLV causes an obligatory right to left transpulmonary shunt through the non-ventilated lung. ${ }^{8}$ The degree of shunt is decreased by the effect of gravity and by hypoxic pulmonary vasoconstriction (HPV) in the non-ventilated lung. The main autoregulatory mechanism responsible for decreasing the shunt during OLV is HPV which diverts blood from the non-ventilated lung to the ventilated lung. HPV occurs primarily in the pulmonary arterioles of about $200 \mu \mathrm{m}$ in diameter. These vessels are advantageously located in very close relation to the small bronchioles and alveoli, which permit rapid and direct detection of alveolar hypoxia. ${ }^{9}$ The occurrence of HPV requires the presence of small pulmonary vessels with intact perivascular tissues. The mechanism of 
HPV is proposed to be either a direct action of alveolar hypoxia on pulmonary vasculature or an alveolar hypoxia-induced release of vasoactive substances. ${ }^{10}$ With normal HPV, numerous clinical studies on OLV have found that the shunt through the non-ventilated lung is usually 20 to $30 \%$ of the cardiac output, as opposed to the 40 to $50 \%$ shunt that might be expected if there were no HPV operating in the non-ventilated lung. ${ }^{11}$

Our patient developed severe hypoxemia upon initiation of OLV. Hypoxemia during OLV may be attributed to several factors including preoperative lung disease, preoperative medications, and hemophilus influenza infection, in addition to malpositioning of the DLT, inadequate ventilation of the dependent lung, as well as the intraoperative use of isoflurane anesthesia. The moderate preoperative abnormalities of PFT and $\mathrm{PaO}_{2}$ cannot explain the severe hypoxemia that developed upon initiation of OLV. Also, the patient was not receiving any preoperative medications, and the culture of hemophilus influenza organism was positive for only $20.000 \cdot \mathrm{mL}^{-1}$. The appropriate positioning of the DLT was confirmed by FOB, and ventilation of the dependent lung was adequate as evidenced by chest auscultation and by a normal $\mathrm{PaCO}_{2}$ during OLV. Isoflurane anesthesia inhibits HPV in the nondependent lung by approximately $21 \%$ and only increases nondependent blood flow from 21 up to $24 \%$ of the total blood flow. ${ }^{12}$ This $4 \%$ increase in the shunt does not explain the occurrence of severe hypoxemia during OLV.

Identifying patients at risk of developing severe hypoxemia during OLV is difficult. A recent report suggests that $\mathrm{PaO}_{2}$ during TLV may be the only intraoperative variable that can predict $\mathrm{PaO}_{2}$ during OLV; a positive relationship exists between these two variables. ${ }^{13}$ However, the $\mathrm{PaO}_{2}$ in our patient with $\mathrm{RB}$ ILD decreased from $500 \mathrm{mmHg}$ during TLV down to $50 \mathrm{mmHg}$ upon initiation of OLV, despite adequate ventilation of the dependent lung with $100 \% \mathrm{O}_{2}$. This hypoxemia may be attributed to excessive shunting in the non-ventilated lung. The shunt would amount to $50 \%$ according to the iso-shunt lines. ${ }^{14}$ Hypoxemia was immediately corrected upon resuming TLV without alternative plans such as continuous positive airway pressure or positive end-expiratory pressure, since the time needed to obtain the lung biopsies was short.

There is evidence that HPV is decreased in certain types of lung diseases including pneumococcal pneumonia, granulomatous pulmonary disease and chronic obstructive pulmonary disease (COPD). ${ }^{15-17}$ Patients with COPD have a decrease in the total cross-sectional area of the pulmonary vascular bed due to anatomic changes from chronic constriction of smooth muscles in response to alveolar hypoxia. ${ }^{18}$ Benumof and Wahrenbrock have shown that these patients have blunted pulmonary vasoconstrictive reflexes. ${ }^{19} \mathrm{We}$ speculate that patients with RB-ILD, similar to COPD patients, may have an impaired HPV response. As a result, transpulmonary shunting may persist in the non-ventilated lung. This might be attributed to the presence of bronchial wall thickening and prominent peribronchovascular interstitium, resulting in a pulmonary vasculature incapable of HPV.

In conclusion, this report presents the case of a patient with RB-ILD who developed severe hypoxemia during OLV. This may have resulted from impaired HPV secondary to the changes in the bronchial wall and the peribronchovascular interstitium associated with RB-ILD. We advise clinicians to be extremely cautious when administering anesthesia to patients with RB-ILD.

\section{References}

1 Moon J, du Bois RM, Colby TV, Hansell DM, Nicholson $A G$. Clinical significance of respiratory bronchiolitis on open lung biopsy and its relationship to smoking related interstitial lung disease. Thorax 1999; 54: 1009-14.

2 Sadikot RT, Johnson J, Loyd JE, Christman JW.

Respiratory bronchiolitis associated with severe dyspnea, exertional hypoxemia, and clubbing. Chest 2000; 117: 282-5.

3 Myers JL, Veal CF Jr, Shin MS, Katzenstein ALA. Respiratory bronchiolitis causing interstitial lung disease. A clinicopathologic study of six cases. Am Rev Respir Dis 1987; 135: 880-4.

4 Yousem SA, Colby TV, Gaensler EA. Respiratory bronchiolitis-associated interstitial lung disease and its relationship to desquamative interstitial pneumonia. Mayo Clin Proc 1989; 64: 1373-80.

$5 \mathrm{King}$ TE. Respiratory bronchiolitis-associated interstitial lung disease. Clin chest med 1993; 14: 693-8.

6 Colby TV. Bronchiolitis. Pathologic considerations. Am J Clin Pathol 1998; 109: 101-9.

7 Niewoehner DE, Kleinerman J, Rice DB. Pathologic changes in the peripheral airways of young cigarette smokers. N Engl J Med 1974; 291: 755-8.

8 Benumof JL. Special physiology of the lateral decubitus position, the open chest, and one-lung ventilation. In: Benumof JL (Ed.). Anesthesia for Thoracic Surgery, 1st ed. Philadelphia: WB Saunders, Inc.; 1987: 104-24.

9 Benumof JL. General respiratory physiology and respiratory function during anesthesia. In: Benumof $\mathrm{JL}$ (Ed.). Anesthesia for Thoracic Surgery, lst ed. Philadelphia: WB Saunders, Inc.; 1987: 39-103. 
10 Sykes MK, Arnot RN, Jastrzebski J, Gibbs JM, Obdrzalek $J$, Hurtig JB. Reduction of hypoxic pulmonary vasoconstiction during trichloroethylene anesthesia. J Appl Physiol 1975; 39: 103-8.

11 Benumof JL, Alfery DD. Anesthesia for thoracic surgery. In: Miller RD (Ed.). Anesthesia, 5th ed. Philadelphia: Churchill Livingstone Inc.; 2000: 1665-752.

12 Benumof JL. Choice of anesthetic drugs and techniques. In: Benumof JL (Ed.). Anesthesia for Thoracic Surgery, lst ed. Philadelphia: WB Saunders, Inc.; 1987: 202-22.

13 Guenoun T, Journois D, Silleran-Chassany J, et al. Prediction of arterial oxygen tension during one-lung ventilation: analysis of preoperative and intraoperative variables. J Cardiothorac Vasc Anesth 2002; 16: 199-203.

14 Benatar SR, Hewlett AM, Nunn JF. The use of isoshunt lines for control of oxygen therapy. Br J Anaesth 1973; 45: 711 .

15 Light RB, Mink SN, Wood LD. Pathophysiology of gas exchange and pulmonary perfusion in pneumococcal lobar pneumonia in dogs. J Appl Physiol 1981; 50: 524-30.

16 Irwin RS, Martinez-Gonzalez-Rio J, Thomas HM III, Fritts $H W J r$. The effect of granulomatous pulmonary disease in dogs on the response of the pulmonary circulation to hypoxia. J Clin Invest 1977; 60: 1258-65.

17 Benumof JL. Hypoxic pulmonary vasoconstriction and infusion of sodium nitroprusside (Editorial). Anesthesiology 1979; 50: 481-3.

18 Casthely PA, Lear S, Cottrell JE, Lear E. Intrapulmonary shunting during induced hypotension. Anesth Analg 1982; 61: 231-5.

19 Benumof JL, Wabrenbrock E. Blunted hypoxic pulmonary vasoconstriction by increased lung vascular pressures. J Appl Physiol 1975; 38: 846-50. 